\title{
Guna dan citra sebagai wujud kreativitas dalam arsitektur nusantara
}

\author{
Studi Kasus Arsitektur Tongkonan Toraja, Mamasa dan Batak Toba \\ Josephine Roosandriantini \\ Universitas Katolik Darma Cendika, Surabaya, Indonesia. jose.roo@ukdc.ac.id
}

\begin{abstract}
Abstrak
Arsitektur nusantara yang merupakan hasil ide kreatif dari masyarakat Nusantara, yang cenderung diciptakan hanya dengan material dan peralatan sederhana. Akan tetapi arsitektur nusantara yang hadir dengan identitas kekunoannya, bukan berarti tidak memiliki nilai kreativitas. Penelitian ini bertujuan untuk mengeksplorasi penerapan teori "Guna dan Citra" dari Mangunwijaya dalam memandang wujud kreativitas dalam arsitekur nusantara. Pengumpulan data dilakukan melalui berbagai kajian literatur untuk menarik kesimpulan tentang bagaimana Teori "Guna dan Citra" diterapkan di Arsitektur Nusantara. Dua objek arsitekur Tradisional, yakni bangunan Tongkonan di Toraja dan Mamasa, serta arsitektur Batak Toba dipilih sebagai objek kajian. Hasil kajian memperlihatkan bahwa penerapan aspek Guna terletak pada pada detail arsitektural konstruksi, tampilan atap dan material yang berkaitan dengan fungsi. Sedangkan penerapan Citra terletak pada penggambaran makna yang dikaitkan kepada penyelesaian bangunan. Selain itu kajian ini semakin menguatkan fakta bahwa Arsitektur Nusantara merupakan hasil ide kreatif masyarakatnya dalam beradaptasi dengan kondisi geogfrafis dan iklim.
\end{abstract}

Kata kunci: arsitektur nusantara, guna, citra, kreativitas,

\begin{abstract}
Nusantara architecture, which is the result of creative ideas from the Nusantara people, tends to be created with simple materials and equipment. However, the Nusantara architecture, which comes with its ancient identity, does not mean that it has no creative value. This study explores the application of Mangunwijaya's "Use and Image" theory in seeing the form of creativity in Nusantara architecture. The data was collected through various literature reviews to conclude how the "Use and Image" theory was applied in Nusantara architecture. Two traditional architectural objects, namely the Tongkonan in Toraja and Mamasa, and the Batak Toba architecture were chosen as study objects. The study results show that the Guna aspect's application lies in the architectural details of the construction, the roof appearance, and materials function-related. Meanwhile, the application of image lies in describing the meaning associated with the building finishing. This further study strengthens the fact that Nusantara architecture is the result of the Nusantara creative ideas in adapting to geographical and climatic conditions.
\end{abstract}

Keywords: nusantara architecture, use, image, creativity

Received: 2020-04-27 | Accepted: 2020-07-21 | DOI: 10.29080/eija.v6i1.898 | Page: 42 - 51

EMARA: Indonesian Journal of Architecture

http://jurnalsaintek.uinsby.ac.id/index.php/EIJA

This article is open access distributed under the terms of the Creative Commons Attribution

ShareAlike 4.0 International License, which permits unrestricted use, distribution, and

reproduction in any medium provided the original work is properly cited. 


\section{Pendahuluan}

Teori Mangunwijaya (2009) mengenai aspek "Guna" dan "Citra" merujuk kepada aspek ketrampilan/kemampuan dan tingkat kebudayaan setempat. Aspek ini mengandung arti bahwa arsitektur bukanlah semata-mata bangunan yang dapat berdiri kokoh dan sekedar memiliki fungsi, namun terdapat aspek lain yang terkandung di dalamnya. Arsitektur haruslah mempunyai kewajaran, benar, dan fungsional. Hal ini dikarenakan arsitektur sejatinya bukanlah bangunan "kosong" belaka melainkan menjadi bagian dari sebuah lingkungan. Faktor lingkungan juga tidak akan lepas dari faktor budaya setempat. Teori Mangunwijaya tidak hanya digunakan untuk menilai atau diterapkan pada bangunan yang megah dan berteknologi tinggi saja, tetapi untuk bangunan yang penuh dengan tradisi-tradisi lokal yang dimiliki oleh bangsa Indonesia, yaitu arsitektur Nusantara (Istanto, 1999).

Arsitektur nusantara merupakan warisan ilmu membangun tempat tinggal dari nenek moyang bangsa Indonesia. Berbagai bangunan arsitektur nusantara dapat dikatakan sebagai sebuah karya hasil ide kreatif masyarakat Nusantara, yang mengolah material alami dengan peralatan sederhana menjadi sebuah bangunan dengan sistem konstruksi yang lebih ramah gempa (Oktavia \& Prihatmaji, 2019).

Sejalan dengan pemikiran dari Mangunwijaya, Prijotomo (2008) menyatakan bahwa keterbatasan bahan, teknologi, dan konstruksi pada pembuatan arsitektur nusantara bukanlah penghalang kreativitas arsitektural dalam menghadirkan tata rupa dan berbagai bentukan yang ada. Dalam kata lain arsitektur nusantara dengan segala keterbatasannya merupakan proses dari sebuah kreativitas itu sendiri.
Berdasarkan pemikiran tersebut dapat terlihat bahwa wujud arsitektur dapat terbentuk dari hasil ide kreatif tiap manusia, sehingga dapat berkembang dengan informasi yang dimiliki berdasarkan pengalaman, memori, dan pengetahuan yang didapat sehari-hari. Kreativitas merupakan kemampuan yang dimiliki individu dalam menghasilkan atau menciptakan sesuatu yang baru dari bentuk yang telah ada (Munandar, 2009). Pendapat tersebut sejalan dengan pengertian kreativitas menurut Riyanti (2019) yang menyatakan kreativitas merupakan kemampuan seseorang untuk melahirkan sesuatu yang baru, baik berupa gagasan maupun karya nyata yang relatif berbeda dengan yang telah ada. Sehingga, pemahaman kreativitas adalah merupakan hasil yang dapat menghasilkan sebuah kombinasi baru yang didasarkan dengan pengetahuan, pengalaman dan memori.

Begitu juga dengan masyarakat nusantara yang hanya bermodalkan peralatan sederhana, material organik yang dimiliki, dengan tuntutan kebutuhan akan tempat berteduh dari panas matahari dan curah hujan membuat mereka lebih kreatif dalam menciptakan wujud arsitektur. Proses ini termasuk runutan kegiatan dalam menghasilkan karya arsitektur, meliputi aktivitas membuat, menggunakan, mengalami dan memahami arsitektur (Marlinda et al., 2013).

Arsitektur nusantara merupakan wujud kreativitas, dimana pemanfaatan yang diperoleh, pengaturan fisik yang tepat dan efisiensi, kenikmatan yang dirasakan di dalam ruang tersebut akan merujuk kapada aspek Guna yang mengarah kepada kemampuan/ keterampilan. Sedangkan aspek Citra akan merujuk kepada tingkat kebudayaan (Mangunwijaya, 1992). 
$\begin{array}{ccc}\text { Penelitian } & \text { sebelumnya } & \text { oleh } \\ \text { Roosandriantini } & \text { (2018) } & \text { telah }\end{array}$

memperlihatkan bagaimana penerapan teori barat (trilogi Vitruvius) dalam arsitektur nusantara serta sudut pandang terhadap sebuah ide kreatif masyarakat nusantara yang dianggap primitif dalam kacamata modernisasi. Sedangkan beberapa penelitian terkait Guna dan Citra dalam arsitektur juga telah dilakukan sebelumnya, diantaranya penelitian Warnata (2017) yang menyatakan bahwa Guna dan Citra tidak dapat lepasi dari konsep trilogi Vitruvius. Sedangkan Hardiyati (2015) telah mengkaji aspek Guna dan Citra pada aspek detail arsitektural pada rumah Jawa. Penelitian Gantini et al (2012) juga telah mengungkap guna dan fungsi pada arsitektur Bale Banjar Adat di Bali.

Berbagai penelitian tersebut memunculkan pandangan bahwa arsitektur nusantara juga telah menerapkan perwujudan Guna dan Citra, sebagai bagian hasil kreativitas masyarakatnya di masa lampau. Penelitian ini bertujuan untuk mengeksplorasi penerapan teori "Guna dan Citra" dari Mangunwijaya dalam memandang wujud kreativitas dalam arsitekur nusantara.

\section{Metode}

Penelitian ini menggunakan metode deskriptif kualitatif untuk memaparkan penerapan teori Guna dan Citra pada arsitektur nusantara. Akan tetapi karena banyaknya wujud fisik arsitektur nusantara di Indonesia, maka penelitian ini hanya akan memilih secara purposif (purposive sampling) objek rumah adat yang digunakan sebagai studi kasus penelitian, yakni arsitektur Tongkonan Toraja, Mamasa dan Batak Toba. Pengumpulan data dilakukan dengan mengumpulkan dokumentasi dari hasil studi lapangan dari obyek kajian. Selain itu data literatur juga dikumpulkan terkait identifikasi proses kreativitas dari setiap objek amatan. Data yang terkumpul kemudian dianalisis untuk megintrepetasi makna pada bagian detail objek kajian penelitian ini. Proses analisis juga akan memerlihatkan temuan di lapangan pada objek kajian dengan konsep Guna dan Citra dari Mangunwijaya. Kesimpulan dapat ditarik setelah makna pada bagian detail objek kajian dapat diinterpetasikan.

\section{Hasil dan Pembahasan}

\section{Arsitekur Tongkonan di Toraja dan Mamasa}

Aspek Guna pada teori Mangunwijaya akan lebih merujuk pada kemampuan / keterampilan dalam menghadirkan kenyamanan (comfort). Dengan peralatan dan material alami kemampuan tersebut dapat dihadirkan dalam arsitektur Nusantara (Mangunwijaya, 1992). Selain itu Guna juga merujuk kepada sebuah fungsi/ kegunaan / pemanfaatan setiap penyelesaian pada setiap detail arsitektural. Sedangkan Citra lebih merujuk pada sebuah makna / gambaran arti dari tiap detail arsitektural, seperti penggambaran teritori, strata sosial, dan menandakan sebuah kekuasaan atau perbedaan status dan lain-lain.

Lingkungan dan pengalaman yang dimiliki oleh masyarakat Toraja, yang berkaitan dengan peralatan, material dalam keseharian mereka memunculkan ide kreatif berupa Tongkonan (rumah adat Toraja dan Mamasa). Salah satu bentuk kreativitas pada bangunan ini ada pada bagian atap. Bentuk atap Tongkonan di Toraja dan Mamasa memiliki bentuk yang hampir sama, yakni bentuk seperti perahu telungkup dengan sudut kemiringan curam (gambar 1). Penyelesaian bentukan atap tersebut dilihat dari konsep konsep Guna berguna untuk memberikan kenyamanan bagi penghuninya saat curah hujan tinggi, 
dimana air tidak akan tertampung di atap tetapi langsung jatuh ke tanah.

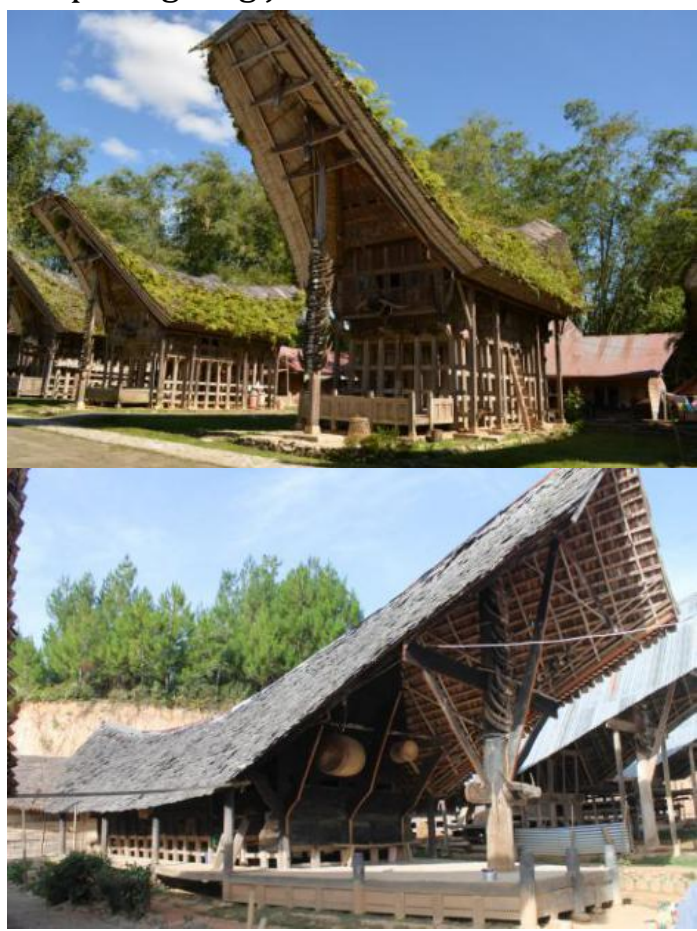

Gambar 1. Bentuk atap Tongkonan Toraja (Sumber: dokumentasi peneliti, 2013)

Sistem konstruksi bangunan Tongkonan menerapkan konstruksi purus lubang yang memiliki jenis pondasi bukan tanam (gambar 2), sebuah sistem konstruksi yang dapat mengakomodir gerakan vertikal sehingga ramah gempa.

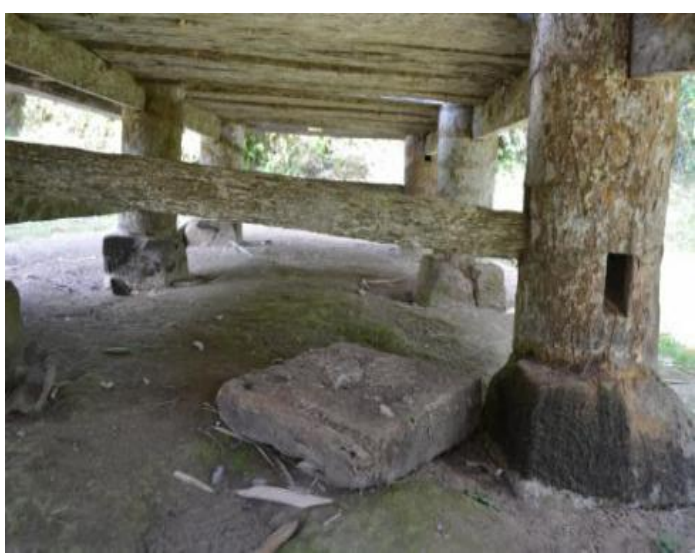

Gambar 2. Konstruksi purus lubang-umpak (Sumber: dokumentasi peneliti, 2013)

Teknik sambungan yang digunakan yaitu dengan melakukan teknik purus lubang dengan menyambung, menyatukan antara tiang (vertikal) dan papan bagian dalam (horisontal). Konstruksi purus lubang tersebut berguna untuk bergoyang saat terjadi gempa bumi, sehingga saat bangunan mendapatkan gerakan horizontal. Saat gempa bumi dan mengakibatkan bangunan jatuh dan miring maka hal itu merupakan posisi yang stabil untuk sebuah rumah adat (Roosandriantini \& Prijotomo, 2016).

Untuk masuk ke bagian dalam bangunan rumah adat Tongkonan, maka akan ditemui wujud fisik sebuah tangga. Tangga tersebut terlihat seperti memasuki ruang di bagian atas (gambar 3). Penggambaran arti dari detail arsitektural bentuk tangga merupakan penerapan Citra pada konsep Mangunwijaya, dimana Citra menjadi elemen pembentuk arsitektur (Burhany, 2010). Istilah Citra lebih kepada menunjukkan suatu image akan posisi dan bentuk tangga yang menunjukkan gambaran sikap sopan atau menghormati si pemilik rumah., karea bagi tamu yang datang secara tidak langsung harus agak sedikit menunduk saat menaiki tangga tersebut.

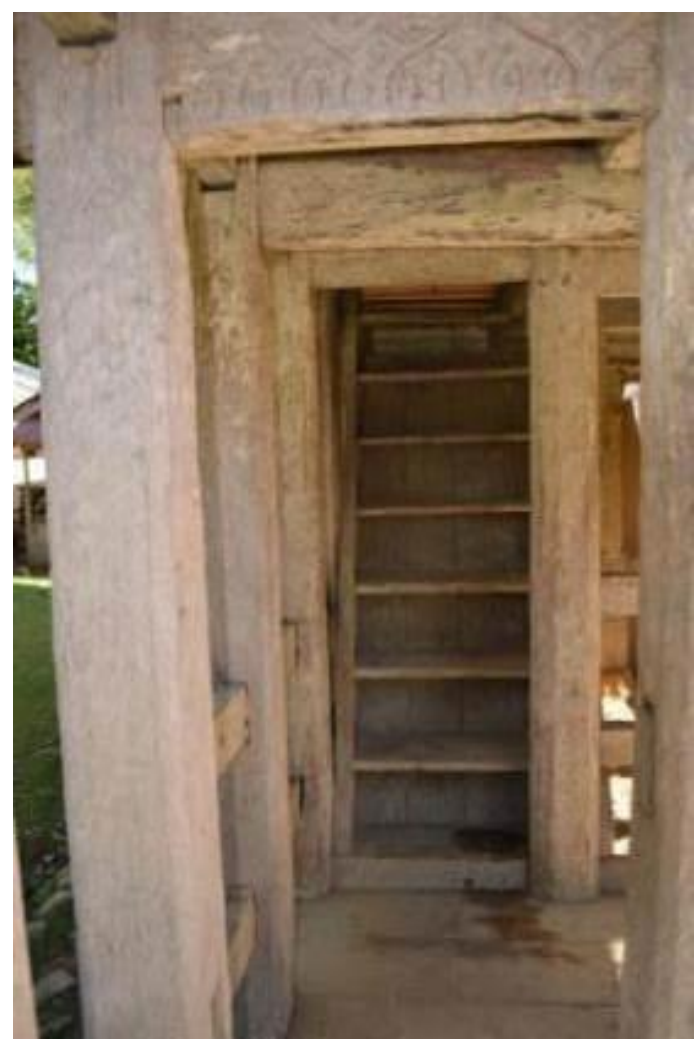

Gambar 3. Tangga di rumah adat Tongkonan (Sumber: dokumentasi peneliti, 2013). 
Pada bagian dalam arsitektur Toraja dan Mamasa terlihat adanya penerapan konsep citra melalui penggunaan sekat untuk menandai perbedaan ruang sehingga terlihat sifat ruangnya, mulai ruang publik, privat dan sakral (gambar 4). Di bagian dalam rumah terdapat ruang publik untuk perapian, tempat menyimpan barang-barang berharga, tempat menyimpan tubuh saat malam hari, dan tempat menyimpan mayat (sebelum dipindahkan ke kubur batu). Terdapat pula perapian di area yang biasa digunakan sebagai tempat berkumpul (gambar 5).

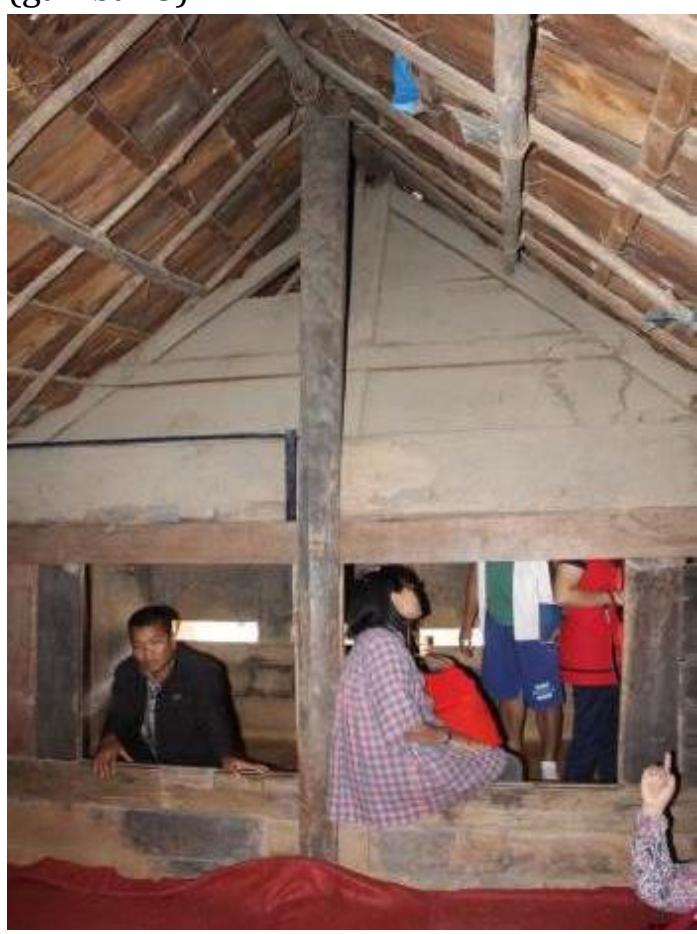

Gambar 4. Sekat pemisah antara ruang publik dan privat di rumah adat Tongkonan Mamasa (Sumber: dokumentasi peneliti, 2013)

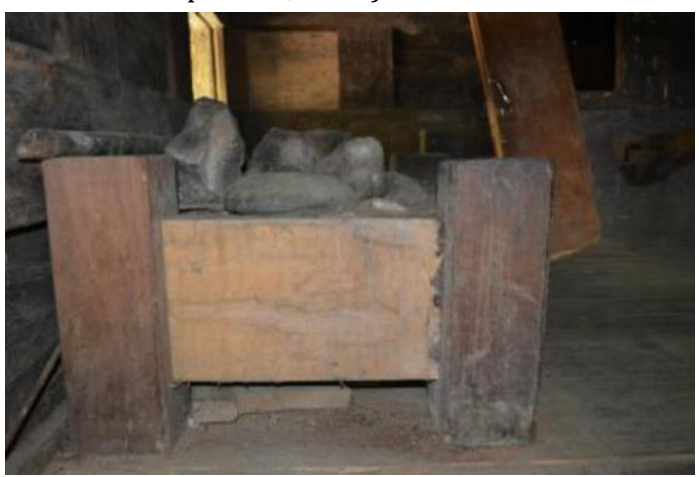

Gambar 5. Perapian didalam rumah adat Tongkonan Toraja (Sumber: dokumentasi peneliti, 2013)
Penerapan konsep teritori yang memisahkan antara area perapian dengan ruang privat terlihat dari adanya penanda berupa perbedaan ketinggian lantai dan balok yang melintang, sehingga harus melangkahkan kaki (gambar 6). Guna merupakan sebuah tinjauan aspek fungsional (Mulyatno, 2013) dan menjadi pembentuk karya arsitektur. Pada rumah adat Mamasa ini yang memiliki partisi yang dijadikan sebagai pembentuk ruang publik dan ruang privat. Fungsional yang terbentuk yaitu terkait kehadiran ruang publik untuk menerima tamu dan ruang privat untuk tempat menyimpan tubuh saat malam (gambar 4). Selain itu juga terdapat juga ruang untuk menyimpan barang berharga lainnya (gambar 7)

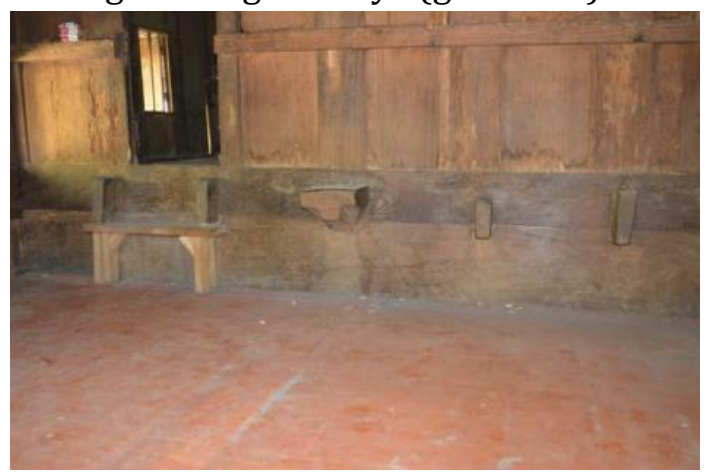

Gambar 6. Penandaan teritori dengan perbedaan lantai (Sumber: dokumentasi peneliti, 2013)

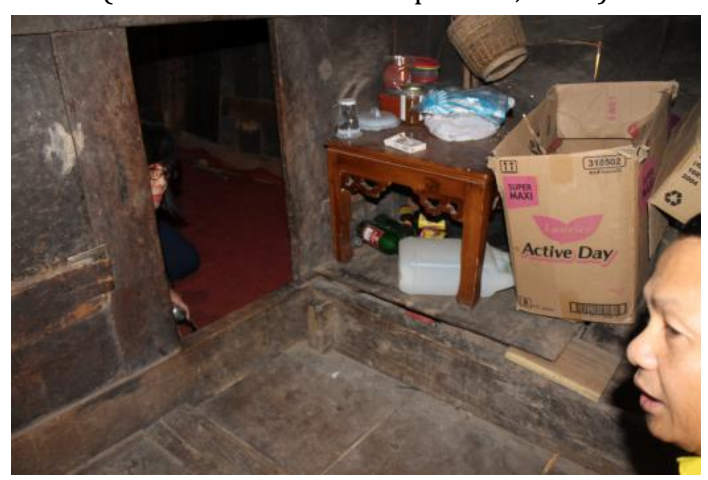

Gambar 7. Ruang untuk menyimpan barang berharga di Rumah adat Tongkonan Mamasa (Sumber: dokumentasi peneliti, 2013)

Makna Citra juga dikaitkan dengan persepsi masyarakat yang melihat bangunan, dimana citra (image) yang muncul saat melihat bangunan yang tersusun dari material alami dipersepsikan sebagai bangunan yang 
kuno dan ketinggalan jaman. Secara positif, image itu sendiri bertujuan untuk memunculkan kekaguman terhadap sesuatu yang manusia lihat. Sehingga dapat diartikan bahwa image yang ditampilkan dari rumah adat Tongkonan terletak pada gambaran kekuatan konstruksi yang tahan terhadap gempa serta kreativitas masyarakat Toraja dalam memanfaatkan ruang dengan berbagai fungsinya.

Berarsitektur adalah sebuah berbahasa dengan berbagai unsurnya seperti material, bentuk, komposisi, ruang, gatra, garis, bidang dan suasana tempat (Hidayatun \& Wonoseputro, 2005). Penerapan bahasa tersebut pada unsur citra dalam arsitektur dapat terlihat pada rumah yang menunjukkan strata sosial pemiliknya. Dalam kasus rumah adat Tongkonan ini strata sosial dapat dilihat hanya melalui jumlah tanduk kerbau yang terpasang pada tulak somba, yakni tiang yang berdiri tegak pada bagian depan rumah Tongkonan (gambar 8). Semakin banyak jumlah tanduk kerbau maka pemilik rumah termasuk dalam strata sosial atas.

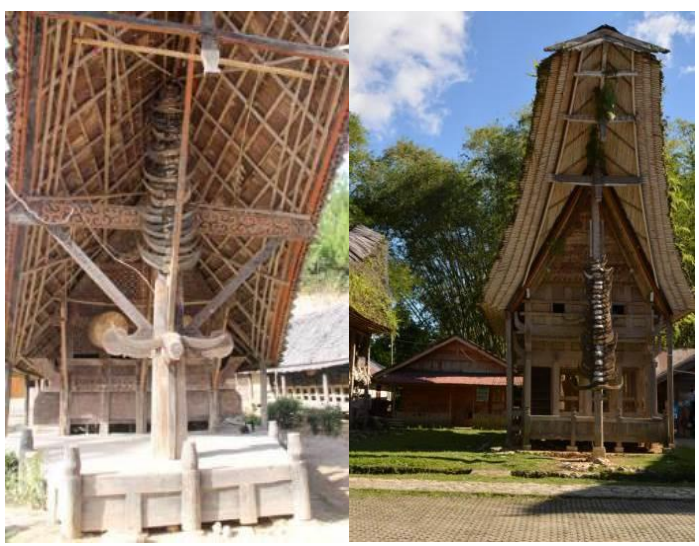

Gambar 8. Tulak Somba (tanduk kerbau) pada rumah adat Tongkonan (Sumber: dokumentasi peneliti, 2013)

\section{Arsitektur Batak Toba}

Wujud fisik arsitektur Batak Toba tidak kalah unik dibandingkan Tongkonan Toraja dan Mamasa. Penerapan konsep Guna dan Citra merupakan salah satu kemampuan yang dimiliki oleh masyarakat nusantara untuk mewujudkan kreativitas dalam penyelesaian bangunannya. Detail arsitektural pada atap rumah Batak Toba memiliki perbedaan tinggi pada tiap ujung atapnya (gambar 9). Atap bagian depan lebih rendah dibandingkan dengan bagian belakang. Perbedaan tinggi atap memiliki makna filosofis mengenai generasi penerus yang lebih baik. Hal ini diidentifikasi sebagai salah satu penerapan konsep Citra pada rumah adat Batak Toba.

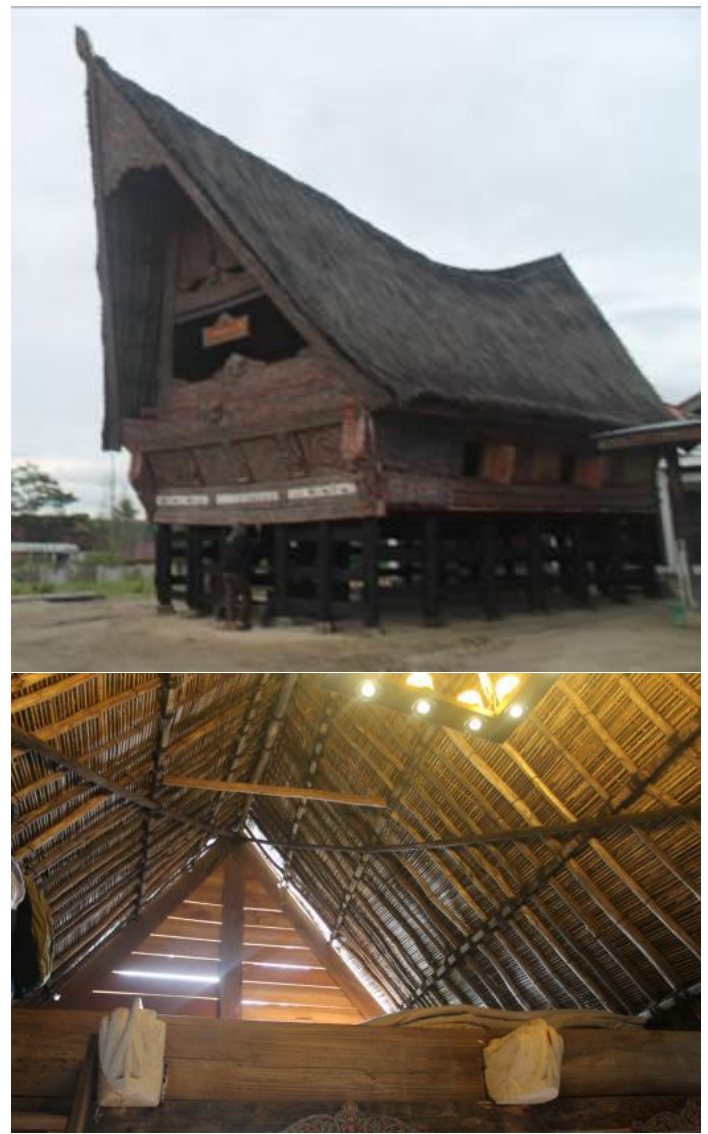

Gambar 9. Atas: tampilan bentuk eksterior atap rumah adat Batak Toba. Bawah: tampilan interior penutup atap rumah adat Batak Toba (Sumber: dokumentasi peneliti, 2018)

Teknik konstruksi dengan sistem purus lubang ini juga diterapkan dalam arsitektur bangunan rumah adat Batak Toba (gambar 10). Teknik konstruksi ini mudah untuk dibongkar pasang dan dapat bergoyang saat terjadi gerakan secara horisontal (gempa). Selain itu sama 
dengan Tongkonan, pondasinya menggunakan umpak (gambar 11). Umpak berguna sebagai alas tiang pada kolong arsitektur Batak Toba. Umpak terbuat dari batu dan diatasnya didirikan kayu. Umpak berfungsi sebagai pondasi yang posisinya tidak di tanam tetapi berada di atas tanah.

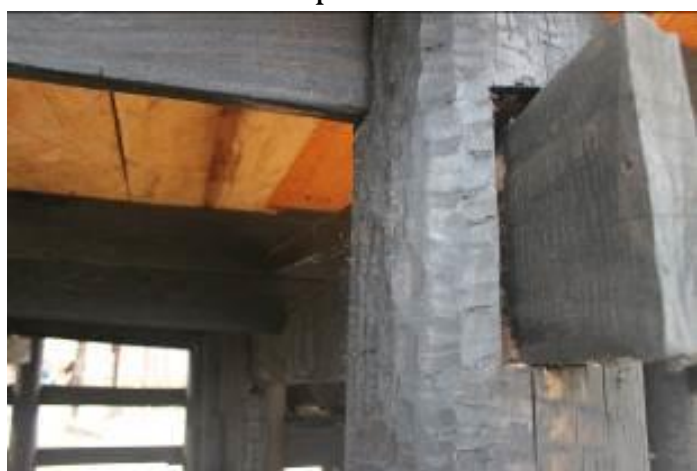

Gambar 10. Teknik konstruksi purus lubang pada rumah adat Batak Toba (Sumber: dokumentasi peneliti, 2018)

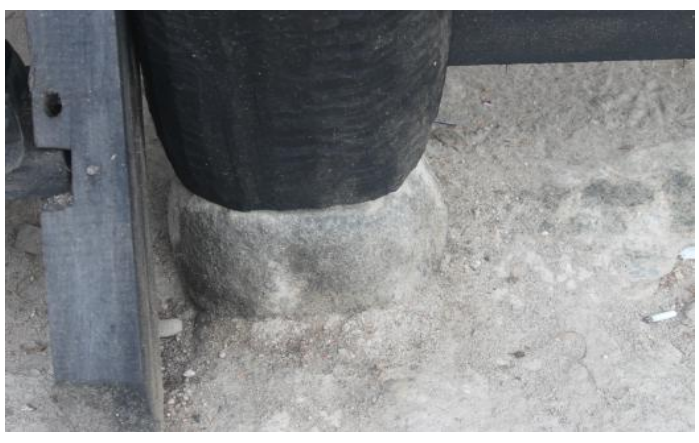

Gambar 11. Teknik pondasi umpak pada rumah adat Batak Toba (Sumber: dokumentasi peneliti, 2018)

Detail usuk pada bagian atap rumah adat Batak Toba juga memiliki kegunaan saat terjadi kebakaran, yaitu dengan memutuskan ikatan rotan pada bagian kayu penghubung bungkulan dengan batahan (gambar 12) sehingga atap dapat terbuka dan jatuh ke arah luar.

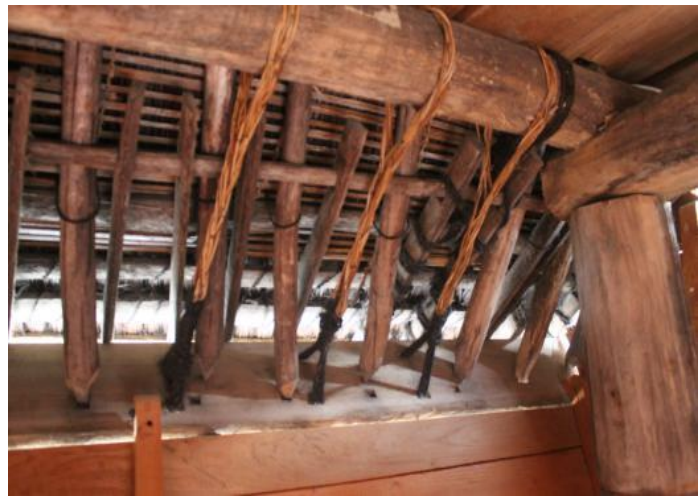

Gambar 12. Ikatan rotan pada bagian bungkulan dan batahan (Sumber: dokumentasi peneliti, 2018)
Pada rumah adat Batak Toba memiliki Sopo yang memiliki kegunaan sebagai tempat penyimpanan / lumbung yang terletak berdekatan dengan rumah induk (gambar 13). Sehingga antara rumah untuk bernaung saat malam hari dengan tempat untuk menyimpan hasil bumi terletak terpisah. Sopo dipisahkan dengan pelataran luas yang digunakan untuk tempat beraktivitas bersama (open public space). Arsitektur diyakini merupakan suatu bentukan yang tercipta untuk memenuhi tujuan tertentu, yakni kebutuhan (needs) dan keinginan (wants) yang diwadahi dalam suatu fasilitas (Kusbiantoro, 2009). Seperti pada peletakan Sopo pada rumah adat Batak memiliki penggambaran arti (citra) penghargaan terhadap kehidupan, sebab padi merupakan sumber kehidupan bagi masyarakat setempat. Bagian tengah Sopo digunakan sebagai tempat menenun dan bersantai.

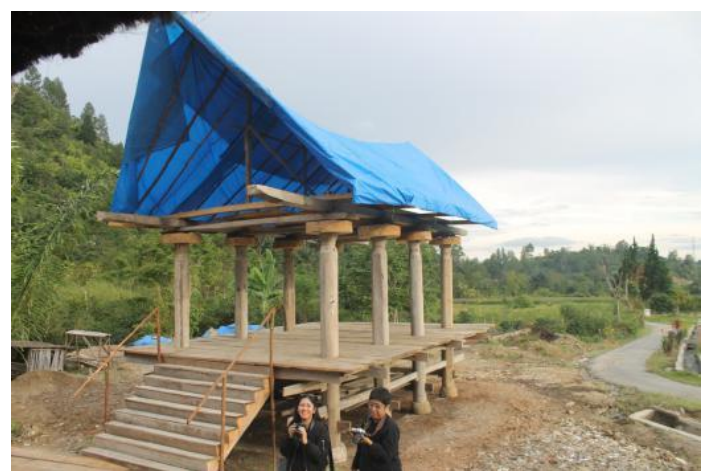

Gambar 13. Bangunan Sopo (lumbung) (Sumber: dokumentasi peneliti, 2018)

Selain itu rumah adat Batak Toba juga memiliki ukiran Gorga yang berwarna (gambar 14). Penggunaan warna dan ornamen Gorga pada rumah adat Batak Toba memiliki citra sebagai penanda status sosial pemilik rumahnya. Warna hitam, merah, dan putih yang digunakan mengacu pada flora dan fauna. Penggunaan warna material berkaitan dengan estetika untuk menghasilkan citra yang diinginkan oleh masyarakat nusantara (Edrees, 2010). Keberadaan Sopo dan Gorga ini merupakan 
perwujudan keinginan dan kebutuhan masyarakat Batak Toba (untuk menyimpan bahan makanan) dengan makna (strata sosial) yang dipercayai oleh masyarakat.

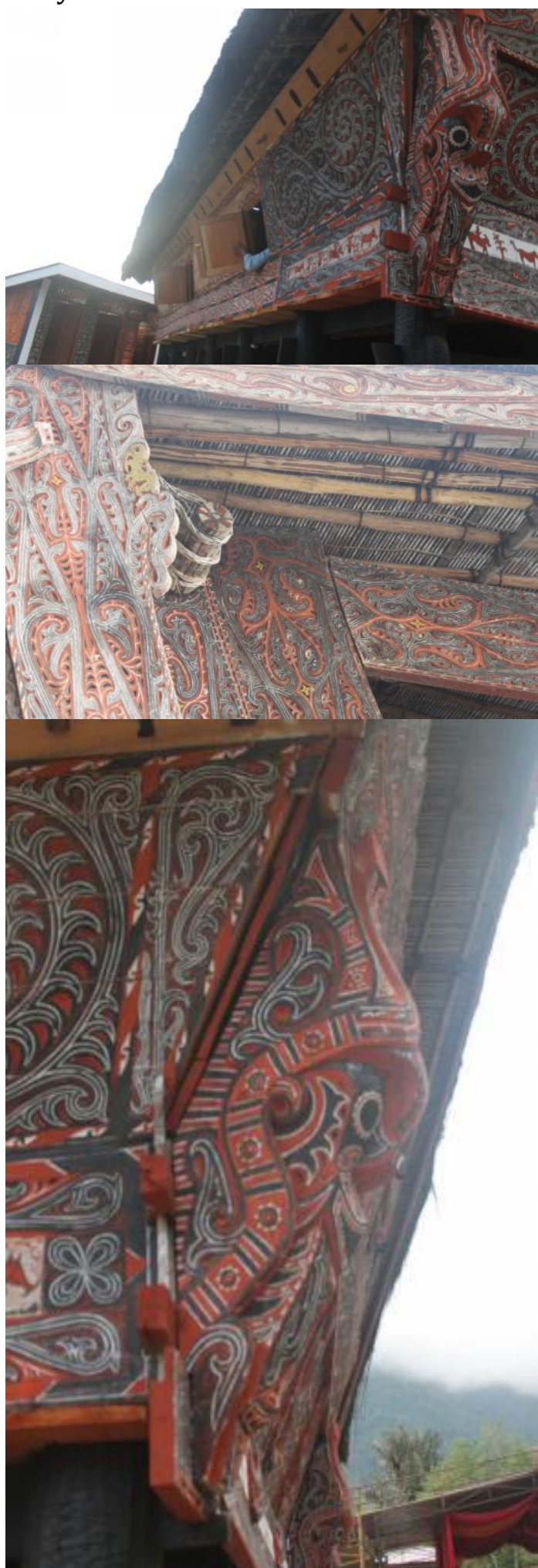

Gambar 14. Ukiran dan warna pada Gorga pada bangunan Batak Toba (Sumber: dokumentasi peneliti, 2018)

\section{Kreativitas \\ dalam \\ masyarakat nusantara}

Pengalaman, pengetahuan dan memori yang dimiliki oleh masyarakat Nusantara mengarah kepada kemunculan ide kreatif atau kreativitas sebagai bentuk penyelelesaian terhadap bangunan (gambar 15). Proses tersebut dilatarbelakangi dari kebutuhan dan keinginan masyarakat nusantara untuk memiliki tempat tinggalnya.

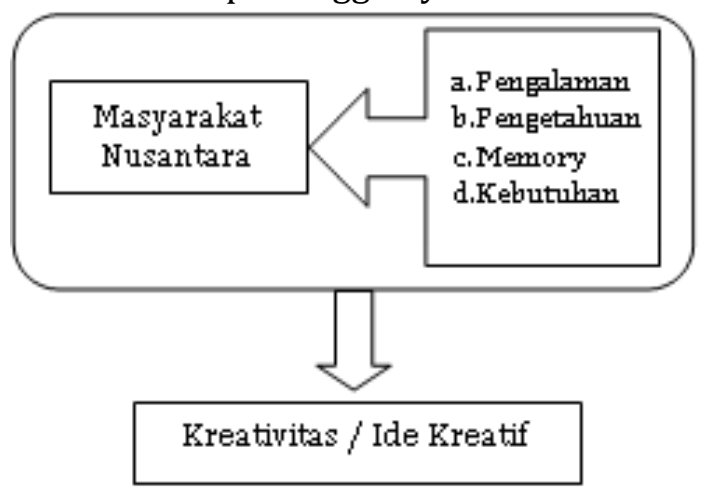

Gambar 15. Skema munculnya kreativitas . ide kreatif dari masyarakat nusantara (Sumber: hasil analisis, 2020)

Ketersediaan material alami, peralatan parang dan pengetahuan yang terbatas, membuat masyarakat Nusantara pun mencari cara untuk dapat mewujudkan tempat tinggal yang dapat beradaptasi dengan iklim lokal. Tingginya intensitas curah hujan menyebabkan hampri semua atap rumah adat memiliki kemiringan yang sangat curam, dengan maksud agar limpasan air hujan dapat dengan cepat mengalir. Hal itu bertujuan agar atap tidak membusuk atau lembab.

Selain itu sering terjadinya gempa bumi di beberapa bagian daerah di Indonesia membuat masyarakat lokal menciptakan teknik sambungan yang adaptif terhadap gempa, salah satunya dengan teknik konstruksi goyang pada sambungan tiang dan balok, yang dapat merespon terhadap daya horisontal dan perputaran akibat gempa bumi. Hal-hal tersebut yang menurut Mangunwijaya, menunjukan pemikiran masyarakat Nusantara memiliki kemampuan untuk 
membuat tempat tinggal yang tahan akan gempa dan dapat mengatasi masalah iklim sesuai dengan konsep Guna dalam teorinya.

\section{Kesimpulan}

Dari sudut pandang konsep Guna dan Citra dari Mangunwijaya, kreativitas dapat dihasilkan walau hanya dengan material alami, peralatan parang seadanya tanpa alat berat sehingga dapat melakukan penyelesaian pada bangunan secara cerdas dan adaptif. Penerapan konsep Guna pada objek kajian ditemukan pada detail arsitekturalnya, khususnya pada penyelesaian konstruksi, tampilan atap, dan material yang berkaitan dengan fungsi. Sedangkan penerapan konsep Citra juga ditemukan pada detail arsitekturalnya, meliputi penggambaran arti / makna yang dikaitkan dengan penyelesaian pada bangunan. Penyelesaian bangunan yang tepat guna dan adaptif terhadap kondisi lingkungan serta memunculkan penanda status sosial dan sifat ruang menjadi bukti nyata perwujudan Guna dan Citra dalam bangunan arsitektur nusantara.

\section{Pernyataan penulis}

Dengan ini penulis menyatakan bahwa penelitian ini terbebas dari konflik kepentingan dengan pihak manapun

\section{Ucapan Terimakasih}

Penulis mengucapkan terimakasih kepada Universitas Katolik Darma Cendika serta semua pihak yang telah mendukung kegiatan penelitian ini.

\section{Referensi}

Burhany, N. R. (2010). Dialog Kritis Trilogi Vitruvius vs Dwilogi Mangunwijaya. Mektek, 10(1), 54-61. http://jurnal.untad.ac.id/jurnal/ind ex.php/Mektek/article/view/537

Edrees, M. B. (2010). Konsep Arsitektur Islami Sebagai Solusi Dalam Perancangan Arsitektur. Journal of Islamic Architecture, 1(1), 16-20. https://doi.org/10.18860/jia.v1i1.1 712

Gantini, C., Prijotomo, J., \& Saliya, Y. (2012). Guna dan Fungsi pada Arsitektur Bale Banjar Adat di Denpasar, Bali. Prosiding Temu Ilmiah IPLBI 2012, 66-68.

https://temuilmiah.iplbi.or.id/guna -dan-fungsi-pada-arsitektur-balebanjar-adat-di-denpasar-bali/

Hardiyati, H. (2015). Guna Dan Citra Detail Arsitektural Pada Rumah Jawa di Surakarta. [Disertasi]. Institut Teknologi Sepuluh Nopember.

Hidayatun, M. I., \& Wonoseputro, C. (2005). Telaah Elemen-Elemen Arsitektur Gereja Puhsarang Kediri Sebuah Pengayaan Kosa Kata Arsitektur Melayu (Nusantara). Proceeding International Seminar on Malay Architecture as Lingua Franca, 308-317.

Istanto, F. H. (1999). Arsitektur' Guna dan Citra' Sang Romo Mangun-In Memoriam: Yusuf Bilyarta Mangunwijaya. DIMENSI: Journal of Architecture and Built Environment, 27(2), 40-47. https://doi.org/10.9744/dimensi.2 7.2.

Kusbiantoro, K. (2009). Pelokalan Arsitektur Gereja Di Indonesia (studi Kasus: Gereja Maria Asumpta - Klaten Karya Y.B. Mangunwijaya). Ambiance, 63-75. https://majour.maranatha.edu/ind ex.php/ambiance/article/view/965 Mangunwijaya, Y B. (1992). Wastu Citra. PT Gramedia Pustaka Utama.

Mangunwijaya, Y. B. (2009). Wastu citra: Pengantar ke ilmu budaya bentuk arsitektur, sendi-sendi filsafatnya, beserta contoh-contoh praktis. PT Gramedia Pustaka Utama.

Marlinda, E. S., Barliana, M. S., \& Krisnanto, E. (2013). Hubungan Pengalaman Berarsitektur Dengan Kreativitas Desain Mahasiswa. invotec, IX(1), 116.

http://jurnal.upi.edu/invotec/view /2179/hubungan-pengalamanberarsitektur-dengan--kreativitasdesain-mahasiswa.html 
Mulyatno, C. (2013). Keutamaan dalam karya-karya kemanusiaan YB. Mangunwijaya. Jurnal Teologi, 2(2), 185-198. https://ejournal.usd.ac.id/index.php/jt/artic le/view/444

Munandar, U. (2009). Pengembangan kreativitas anak berbakat. Rieneke Cipta.

Oktavia, A. M., \& Prihatmaji, Y. P. (2019). Tektonika rumah gadang sebagai bentuk struktur konstruksi yang ramah gempa. SENADA (Seminar Nasional Desain Dan Arsitektur), 2, 655-663. https://eprosiding.stdbali.ac.id/index.php/senada/article /view/113

Prijotomo, J. (2008). Pasang surut arsitektur Indonesia. Wastu Lanas Grafika.

Riyanti, B. P. D. (2019). Kreativitas dan Inovasi di Tempat Kerja. Penerbit Unika Atma Jaya Jakarta.

Roosandriantini, J. (2018). Terapan Trilogi Vitruvius Dalam Arsitektur Nusantara: EMARA: Indonesian Journal of Architecture, 4(2), 77-84. https://doi.org/10.29080/eija.v4i2. 267

Roosandriantini, J., \& Prijotomo, J. (2016). Konstruksi Goyang (Konstruksi Tanpa-Paku) sebagai Terapan Firmitas di Arsitektur Nusantara. Proceeding Seminar Nasional Jelajah Arsitektur Tradisional 2016, 29-43.

Warnata, I. N. (2017). Guna dan Citra dalam Arsitektur. Undagi: Jurnal Ilmiah Jurusan Arsitektur Universitas Warmadewa, 5(1), 1-8.

\section{Kontribusi Penulis}

Josephine Roosandriantini berkontribusi dalam penyusunan konsep penelitian, metodologi, pengumpulan data dan analisis serta penyusunan draft artikel dan revisi. 